\title{
Workplaces Spirituality Towards Leadership Effectiveness
}

\author{
Fadillah Ismail $^{1}$, Intan Sazrina Saimy ${ }^{2}$, Nur Amalina Mohd Rosli ${ }^{3 *}$, \\ Nisha Naderra Binti Mansor ${ }^{4}$
}

${ }^{1,2,3,4}$ Fakulti Pengurusan Teknologi dan Perniagaan, Universiti Tun Hussein Onn Malaysia, 86400 Parit Raja, Batu Pahat, Johor, MALAYSIA

*Corresponding Author

DOI: https://doi.org/10.30880/ojtp.2019.04.02.001

Received 25 ${ }^{\text {th }}$ June 2018; Accepted $25^{\text {th }}$ May 2019; Available online $30^{\text {th }}$ September 2019

\begin{abstract}
In Malaysia, the research about workplace spirituality towards leadership effectiveness is rarely done. The workplace spirituality indicates the meaningful work, sense of community and alignment of values. The purpose of this study is to determine the relationship between workplace spirituality towards leadership effectiveness. There were three hypotheses that had been examined; meaningful works, sense of community and alignment of values. The research has been conducted to the volunteers at Civil Defense, Batu Pahat. This research has used the quantitative approach where the questionnaire has been distributed to 36 volunteers at Civil defense of Batu Pahat, Johor. Data has been collected has been analyzed using Statistical Package for Social Science (SPSS) version 24.0. Based on the finding, there has been a significant relationship between workplaces spirituality and leadership effectiveness. The workplace spirituality has given a positive effect on the leadership effectiveness in Civil Defense of Batu Pahat, Johor. The data has been collected can helps civil defense and also the leader itself.
\end{abstract}

Keywords: Leadership, leadership effectiveness, spirituality, workplaces effectiveness

\section{Introduction}

In today society, the organization must follow the flow of survival and development in society. Each organization needs a leader to lead the group in order to achieve organization goals. The leader defined as a person that responds to influence their follower and direct into the objective (Sethuraman, \& Suresh, 2014). Besides the leadership effectiveness, workplace spirituality is one of the important components in the organization. The two of the components has gone hand to hand because is an important key to all organization to ensure the vision and mission organization can be achieved. Workplace spirituality has a lot of theoretical evidence by the past researcher. In the previous research, workplaces spirituality has been related to religion (Sukanya, 2014). According to Weitz, Vardi \& Setter (2012), the workplace spirituality could help in improvement of employee's productivity and contribution to the organization, employee's problem solving and intuitive capacities and organizational. Leadership effectiveness and workplace spirituality is an important element that an organization must observe to get a better working environment.

In the past two decades, the issue of leadership has been related to other organizational factors and more remarkable (Duckett \& Macfarlane, 2003). In Malaysia, leadership effectiveness and workplaces spirituality are not treated as an important component in a company. Daniel \& Chatelain-Jardon (2015) has considered changing in both demographic and religious aspects, besides the improvement in standard living as main drivers for the popularity term of spirituality in workplaces. In the organization instead of workplaces spirituality, the leader effectiveness also the important key to ensure the organization can run well. The Civil Defense, Batu Pahat, Johor has been selected as a research background.

*Corresponding author: menarosli93@gmail.com

2019 UTHM Publisher. All rights reserved. penerbit.uthm.edu.my/ojs/index.php/Oj-TP 
Civil Defense is one of the public organizations. The volunteer of civil defense of Batu Pahat, Johor as research respondents. This research has selected civil defense as a research study is because to find the level of workplace spirituality among the volunteer. The research has also been conducted at civil defense is to find out how far the workplaces spirituality can be effective to the leadership effectiveness of the leader at civil defense.

\subsection{Problem Statement}

The most of common vocabulary has related spirituality as a religion but not related the spirituality to the workplaces or leadership. Bhatia \& Arora (2017), Bosch L. (2009), Benefiel, Fry \& Geigle (2014) and Kumari (2014), the studies have been researched into workplaces spirituality. Bhatia \& Arora (2017) has reported the result of the research on the importance of workplaces spirituality. The studies using the many sources of the journal, online resources, and research paper to keep the view of the objective. According to the findings Kumari (2014), spirituality has become life-blood of business and empowered people to look to self-interest to make different and contribute to society.

Since decades, that research related to spirituality with the workplace and leadership effectiveness not been much explored by people (Sukanya, 2014). The spirituality and the leadership effectiveness it the most important factors to ensure the environment of the organization in the good condition and the spirituality as a lead the individual to contribute to the organizational and also to the society beside the leadership effectiveness (Kumari, 2014). The employees and leader have related to workplaces spirituality and effectiveness. Therefore, one of the main reasons the study has been made is to find the relationship between workplaces spirituality and leader effectiveness. According to Sukanya (2014), the previous research the openness, answerability, and responsibility is overall leadership effectiveness felt by employees that promote spirituality at work. Therefore, the research has been studied to find more detail about the level of the leader's effectiveness and investigate the characteristic of a leader that can lead employees.

Leadership effectiveness is one of the issues in the organizational. The leader is must someone has a visionary leader that can lead the organization to success. Since 2010, the turnover rate has been increased. That is the worrying issue and gives a big impact on the organizational and also to the followers. The leadership effectiveness in each organizational is differenced. The success of organizational depends on the effectiveness of the leader to lead their followers. The leader effectiveness depends on what kind of leadership that they used. The leadership has been categories into three are transactional, transformational and transcendental leaders. Each of the leadership has different ways to lead their followers or employees.

In past decades, the relationship between leadership effectiveness and workplace spirituality not much had been researched. Included Sukanya (2014) and Zandi, Sulaiman \& Rashed (2015) their only studies in the employee perspective by related to the previous studies but not in a specific area such as the specific area organizational. The result of the researcher shows the leadership effectiveness can make an employee follow their leader. And the organizations that understand leader success can give effect and implication to workplace spirituality. Workplace spirituality can be influenced by the effectiveness of leadership. Workplace spirituality has been bringing to the organizational and make the employees understand my mind and spirit to make employees find the meaning and purpose of their work.

Unfortunately, in Malaysia that has very limited studies that related to the relationship between workplace spirituality and leadership effectiveness in the public sector. To concentrate on gap, the studies has been focussing to the Civil Defense at Batu Pahat, Johor and to ensure the result can give the improvement to the organizational, volunteer at Civil Defense and the leader the studies focus to find the level of workplaces spirituality and the level of leadership effectiveness based on perspective of volunteer at Civil Defense. And another objective of the studies is to find the relationship between workplaces spirituality and leadership effectiveness.

\subsection{Research Objectives}

The objective of the research consists three main objectives which are:

i. To determine the level of leadership effectiveness base on volunteer perspective at Civil Defense Batu Pahat district.

ii. To determine the level of workplaces spirituality among volunteer at Civil Defense of Batu Pahat district.

iii. To explain the relationship between workplaces spirituality and leadership effectiveness at Civil Defense of Batu Pahat district.

\subsection{Research Scope}

The scope of the study as below:

i. The research will be conduct at Civil Defense of Batu Pahat district.

ii. The research respondent focusses to volunteer at Civil Defense of Batu Pahat district.

iii. The set of questionnaires for evaluate the level of leadership effectiveness and workplaces spirituality toward their leader at Civil Defense of Batu Pahat district. 


\section{Literature Review}

\subsection{Leadership}

The leader is someone can lead their group to ensure the work can do in time. The successful leader is someone can ensure the goals of an organization can be achieved. According to Jenkins (2013), the basis of good leadership has a strong personality and self-sacrificing devotion to organizational. Meanwhile, Ololube (2013) has described the leadership involves a responsibility that requires performance by using the existing resources and ensure organizational in cohesive and coherent in between the process. The main component leadership by West perspective divides by two that individual and professional life. The leadership study must be approach critical and reflexive with attention should be given in situation, events, ideas, social practices and process (Ford, 2010). The good leader must be oriented leaders compared to static leaders with focus make the interaction between itself and followers.

\subsection{Leadership Effectiveness}

The leadership in organizational are important because of that one of important function in management. The leader has defined as the persons have holds a higher position and someone that superior position in the company, the leader is able to control the employees also can influence the employees. In a company Malaysia, they are using a different style in order to guide their employees and make sure the goals or objective of organizational accomplish. According to the Nisbett (2004), the two different perspectives have been highlighting how and why the Western and Islamic has to guide to a different direction. The leadership effectiveness can be defined as a leader that has capacities to maintain his or her ability to control the followers in achieving goals.

\subsection{Spirituality}

The spirituality is one of the important tools in the workplaces because that is the direction to ensure organizational in good condition and workers has a teamwork spirit. According to Kelly et al (2011), spirituality is the desire of humanity for connection with transcendent, the desire for integration of the self into meaningful work and realization of on e's potential that consistent. The spirituality also as an element to build trust between employers and their employees that can give a positive impact to organizational performance.

\subsection{Workplaces Spirituality}

The workplace spirituality can come from the individual, team or organization. Workplaces spirituality has the potential to affect the effectiveness of leadership. Based on Marschke et al (2011) the workplaces spirituality is when people can find the meaning of their work and feel involved to the organizational climate, they become the healthy and happier worker that engaged in a collaborative manner and has fully poured their potential to their work also bring their entire selves to the organizational. In the workplaces spirituality also has an individual that defined as psychological climate when people has been considered their internal life with meaningful work and place in the situation of the community (Wulandari, 2014). The main component that indicates the workplace is meaningful work, sense of community and alignment of values.

\subsection{Meaningful Work}

The meaningful work is one component that indicates in workplaces spirituality. According to Houston (2014), the spirituality view is one of the individuals find for meaning and purposes of their work besides paycheck or receives.

\subsection{Sense of Community}

The sense of community involves a deep connection with other or concern between employees and peers. According to Munda (2011), these communities in the deep sense with connectedness among themselves include genuine, expression and support caring for each other.

\subsection{Alignment of Value}

The second indicates or component of workplaces spirituality that involves the personal and belief of an individual has a related to the mission and purpose of the organization. The alignment of value is a component that much concerned to their employee's welfare with involves the belief of organizations that have appropriate values and a strong sense of right and wrong (Ashmos \& Duchon, 2000). the alignment between employees and organizational values implies a significance of value organizations that important to the organization are espoused and employees support identify with those value (Saks, 2011). 


\subsection{Conceptual Framework}

The theoretical framework was being built based on the literature review. Figure 2.1 shows the theoretical framework.

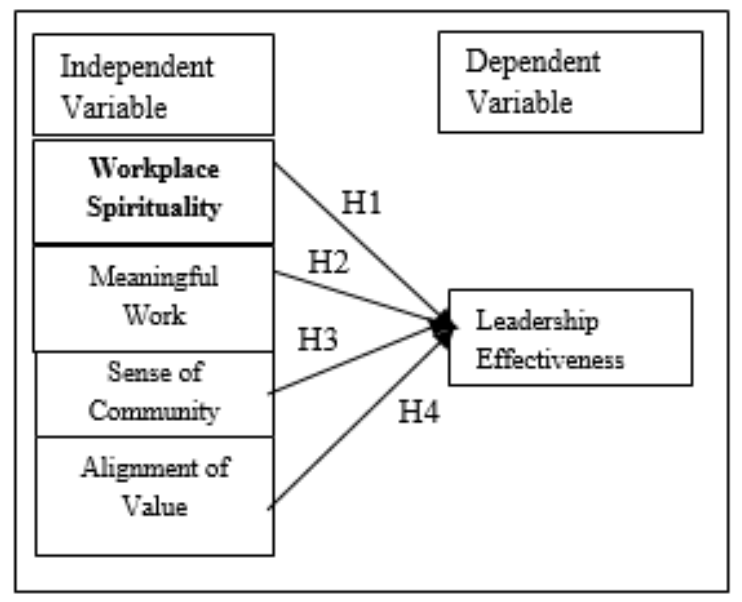

Figure 2.1: Conceptual Theoretical Framework Source: (Petchsawang \&Duchon, 2009)

H1: The higher spirituality in workplaces, the greater leadership effectiveness.

H2: The higher meaningful of work, the higher can affect the leadership effectiveness.

H3: The higher sense of community, the higher can affect to leadership effectiveness.

H4: The higher alignment of values in workplace spirituality, the greater is leadership effectiveness.

\section{Research Methodology}

This part discusses the methodology that has been used to carry out the study.

\subsection{Research Design}

This study using quantitative research to collected data from the quantity of respondent will be quantified and result will be analyzed. The collected data will be analyzed by using statistical analysis. Quantitative research is been using in this study based on collecting data using survey questionnaire. The purpose using survey questionnaire to collect the data is to find the relationship between workplaces spirituality and leadership effectiveness among volunteer at civil defense.

\subsection{Population and Sample}

The target population is volunteers at civil defense that has been register with civil defense as a volunteer at Batu Pahat. The population of volunteers at Batu Pahat is 40 people. But according the Krejcie and Morgan (1970), to the sample size for this research collected was 36 respondents.

\subsection{Research Instrument}

This study had been conducted by using survey questionnaire that has been distribution to volunteer at civil defense. The most questions in the questionnaire were established, existing model with some modification from the original model. The questionnaire of this study contained the three sections A, B and C. Section A: the demographic of respondent, Section B: the independent variable that contains four variables is workplace spirituality, meaningful work, sense of community and alignment of work. For Section C: the dependent variable is the leadership effectiveness. In section B and $\mathrm{C}$ using the Likert Scale from 1 (strongly disagree) to 6 (strongly agree). The Likert Scale can determine the respondent rating or opinion. The Likert Scale can determine the level of workplaces spirituality and leadership effectiveness.

\subsection{Sampling Design}

The sampling design of this study using random sampling that respondent is known. The sample is taken from a larger population and be selected using a year. Firstly, find out the target of the population then determine the sampling frame and apply suitable data method. Lastly, conduct the collection data.

\subsection{Data Analysis}

The data has been collected from the respondent will be gathered and summarized by using Statistical Package for the Social Science (SPSS) software. By using SPSS software, the data can be summarized and can help in figure out of the 
data that has been measured. The SPSS has analysed the demographic data, data reliability and the normality of the data. The hypotheses of the study also can determine if can be accepted or rejected.

\section{Findings and Discussion}

\subsection{Reliability Analysis Instrument}

The main purpose of this study was to verify the reliability of the survey instrument. To acknowledge the internal consistency of reliability was by using the Cronbach's Alpha. It is the degree to which an instrument will give similar results for the same individuals at different times. Reliability can take on values inclusive of 0 to 1.0.

\subsubsection{Reliability test for pilot study}

Table 4.1 below shows the reliability statistics for the pilot study. The Cronbach's alpha for reliability test of pilot test was 0.853 , which was higher than 0.6 , thus it was estimated that the data collected was reliable to be used for the research. The number of respondents used for pilot study was 36 respondents.

Table 4.1 - Reliability statistic for pilot test.

\begin{tabular}{ll}
$\begin{array}{l}\text { Cronbach's } \\
\text { Inhs }\end{array}$ & $\begin{array}{l}\text { N } \\
\text { of Items }\end{array}$ \\
\cline { 2 - 2 } .853 & 29 \\
\hline \hline
\end{tabular}

\subsubsection{Reliability test for real study}

Table 4.2 below shows the reliability test. The overall reliability data scored is 0.853 which is higher than 0.6 that shows the data reliable to use for the research. The item consists 29 items with 6 Likert's scale. For the meaningful of work, the Cronbach's Alpha is 0.751 . Meanwhile, the sense of community the score is 0.627 . The alignment of community the score of reliability is 0.752 . Lastly, for the dependent variable is leadership effectiveness the score is 0.635 . It shows the entire item reliable to use for the research.

Table 4.2 - Reliability statistics.

\begin{tabular}{|c|c|c|c|c|}
\hline & \multicolumn{4}{|c|}{ Reliability Statistics } \\
\hline & & $\begin{array}{l}\text { Cronbach's } \\
\text { Alpha }\end{array}$ & $\begin{array}{l}\text { Cronb } \\
\text { on } \\
\text { Stand }\end{array}$ & $\begin{array}{c}\text { ased } \\
\mathbf{N}\end{array}$ \\
\hline \multicolumn{2}{|c|}{ Overall } & .853 & .855 & 29 \\
\hline \multirow{3}{*}{$\begin{array}{l}\text { I } \\
\text { V }\end{array}$} & Meaningful Work & .751 & .757 & 7 \\
\hline & Sense of Community & .627 & .637 & 8 \\
\hline & Alignment of Values & .752 & .765 & 7 \\
\hline $\begin{array}{l}\text { D } \\
\text { V }\end{array}$ & Leadership & .635 & .638 & 7 \\
\hline
\end{tabular}

\subsection{Analysis of Demographic Profiles}

A total 36 questionnaire was collected from in the Department of Civil Defence, Batu Pahat, Johor. The result obtained was calculated using SPSS and described. Showing the result in Table 4.3, the male respondents are higher than female respondents with 24 male respondents (66.7\%) and 12 female respondents. The race of respondents is $100 \%$ Malay. There are no other races involved. From the research, the result showed the higher range of age among volunteers is $27-$ 30 years old with 12 respondents. The percentage of the respondents in the range of age $27-30$ years old is $33.3 \%$. The second highest age of respondents is 23-26 years old with $25.0 \%$, that 9 respondents in the age of 23-26 years old, followed by $19-22$ years old and 31-34 years old with (16.7\%) and $13.9 \%$ respectively. While, the 35 years old and above has the lowest percentage of $11.1 \%$. Meanwhile, the marital status shows that single respondents are higher than married respondents with 19 respondents (52.8\%). Married respondents are 17 respondents with $47.2 \%$. Lastly, current work was calculated and the result shows in Table 4.1. Thus, this shows that among the respondents' current work, the public sector was 22 respondents with $61.1 \%$. Following the public sector, the second higher respondent current work is the private sector which was $27.8 \%$ representing 10 respondents. The third highest is students with 3 respondents $(8.3 \%)$. The lowest respondent in current work is other with 1 respondent only. 
Table 4.3 - Demographic profiles.

\begin{tabular}{|c|c|c|c|}
\hline & & Frequency & Percentage (\%) \\
\hline \multirow[t]{2}{*}{ Gender } & Male & 2 & 66 \\
\hline & Female & 1 & 33 \\
\hline \multirow[t]{4}{*}{ Races } & Malay & 3 & 100 \\
\hline & Chinese & 0 & 0 \\
\hline & Indian & 0 & 0 \\
\hline & Other & 0 & 0 \\
\hline \multirow[t]{5}{*}{ Age } & 19-22 years & 6 & 16 \\
\hline & 23-26 years & 9 & 25 \\
\hline & $27-30$ years & 1 & 33 \\
\hline & 31-34 years & 5 & 13 \\
\hline & 35 years and above & 4 & 11 \\
\hline \multirow[t]{2}{*}{ Marital Status } & Single & 1 & 52 \\
\hline & Married & 1 & 47 \\
\hline \multirow[t]{4}{*}{ Current Work } & Student & 3 & 8 \\
\hline & Public Sector & 2 & 61 \\
\hline & Private Sector & 1 & 27 \\
\hline & Other & 1 & 2 \\
\hline TOTAL & & 3 & 100 \\
\hline
\end{tabular}

\subsection{Descriptive Analysis}

\subsubsection{Independent Variable: Workplace Spirituality}

Table 4.4 below shows the level of workplace spirituality at the Department of Civil Defence Batu Pahat is in level 4.00 (very high) with the frequency of 27 (75\%). Ranking second with 8 respondents $(22.2 \%)$ is level 3.00 of high level. For the level 2.00 , there is only one respondent with the percentage of $2.8 \%$.

Table 4.4 - Level of workplace spirituality

\begin{tabular}{llll}
\hline Level & Rank & Frequenc & $\begin{array}{l}\text { Percentag } \\
\text { e }\end{array}$ \\
\hline 2.00 & Medium & 1 & 2.8 \\
3.00 & High & 8 & 22.2 \\
4.00 & Very High & 27 & 75.0 \\
Total & & $\mathbf{3 6}$ & $\mathbf{1 0 0 . 0}$ \\
\hline \hline
\end{tabular}

Table 4.4 below shows the total mean and standard deviation for workplace spirituality that has three variables is meaningful work, sense of community and alignment of values. From all variables, the meaningful work has highest mean which is 4.92 and the total standard deviation is 0.490 . The second-high mean is sense of community which is 4.91 and the standard deviation is 0.43 . The lowest mean is alignment of values which was 4.62 meanwhile the standard deviation is 0.558 . From the three variables, the overall of total mean is 4.82then the standard deviation for the variable is 0.416. The workplace spirituality in department of civil defence of Batu Pahat, Johor has in level very high that two from three components as shows a very high level which was meaningful work and sense of community, then, alignment of value in high level.

Table 4.5 - Total mean for workplace spirituality

\begin{tabular}{|c|c|c|c|}
\hline $\begin{array}{l}\text { Workplace } \\
\text { Spirituality }\end{array}$ & $\begin{array}{l}\text { Mea } \\
\text { n }\end{array}$ & $\begin{array}{l}\text { Std. } \\
\text { Deviati }\end{array}$ & Level \\
\hline Meaningful Work & 4.92 & .490 & Very High \\
\hline Sense of Community & 4.91 & .428 & Very High \\
\hline Alignment of Value & 4.62 & .558 & High \\
\hline Total Mean & 4.82 & .416 & Very High \\
\hline
\end{tabular}




\subsubsection{Dependent Variable: Leadership Effectiveness}

Table 4.6 shows the level of leadership effectiveness in the Department of Civil Defence, Batu Pahat, Johor is high is in level 3.00 with 18 respondents (50\%). The next level with 17 respondents and $47.2 \%$ is very high in level 4.00 .

\begin{tabular}{llll}
\multicolumn{4}{c}{ Table 4.6 } \\
\hline Lev & Level for leadership effectiveness \\
\hline 2.00 & Medium & Frequenc & Percen \\
3.00 & High & 18 & 2.8 \\
4.00 & Very High & 17 & 50.0 \\
Tota & & $\mathbf{3 6}$ & 47.2 \\
\hline
\end{tabular}

\subsection{Normality Test}

As depicted in Table 4.7, this research uses the Shapiro-Wilk test to identify the normality test as the sample size are 36 respondents which is less than 50 respondents. The $\mathrm{P}$ value range that has more than 0.05 shows the data distributed has normal distribution. Therefore, the research needed using the Pearson correlation test. However, the data attribute shows the $\mathrm{P}$ values less than 0.05 , the data is not normal and the research need used the Spearman correlation test. By referring to the result in Table 4.7, the data is not normally distributed because of the value for normal data $p>0.05$, thus, the Spearman" rho correlation test is required in order to achieve the objectives of the study.

Table 4.7 - Normality test

\begin{tabular}{llll}
\hline & \multicolumn{2}{l}{ Shapiro-Wilk } & \\
& Statistic & df & Sig. \\
\hline $\begin{array}{l}\text { Meaningful } \\
\begin{array}{l}\text { Sense of } \\
\text { community }\end{array}\end{array}$ & .847 & 36 & .00 \\
$\begin{array}{l}\text { Alignment of } \\
\text { value }\end{array}$ & .837 & 36 & .00 \\
$\begin{array}{l}\text { Leadership } \\
\text { effectiveness }\end{array}$ & .903 & 36 & .00 \\
\hline
\end{tabular}

\subsection{The Correlation Analysis}

The Spearman correlation, with $\mathrm{r}$ value in Table 4.8 proved there is positive relationship between workplace spirituality and leadership effectiveness. The value of correlation, $r$ between meaningful work and leadership effectiveness $(0.630)$ the relationship for two variables is moderate, sense of community and leadership effectiveness (0.727), shows the strong relationship. The alignment of value $(0.528)$ also shows the moderate relationship between the two variables. The workplace spirituality and leadership effectiveness (0.688) shows moderate relationship.

Table 4.8 - Result of correlation analysis

\begin{tabular}{lll}
\hline & Correlation, $\mathbf{r}$ & $\begin{array}{l}\text { Leadership } \\
\text { Effectiveness } \\
\text { (LE) }\end{array}$ \\
\hline Meaningful Work (MW) & Correlation Coefficient & .630 \\
& Sig. (2-tailed) & .003 \\
& $\mathrm{~N}$ & 36 \\
Sense of Community (SC) & Correlation Coefficient & .727 \\
& Sig. (2-tailed) & .000 \\
& $\mathrm{~N}$ & 36 \\
Alignment of Values (AV) & Correlation Coefficient & .528 \\
& Sig. (2-tailed) & .011 \\
& N & 36 \\
Workplace Spirituality & Correlation Coefficient & .688 \\
& Sig. (2-tailed) & .004 \\
& N & 36 \\
\hline
\end{tabular}




\subsection{The Relationship between Workplaces Spirituality and Leadership Effectiveness}

The result from the correlation coefficient, $r$ test shows the factors between workplace spirituality and leadership effectiveness. First, the correlation value of the meaningful work is 0.630 with significant 0.003 that suggest there is statistically significant relationship between the two variables. Second, the correlation coefficient for sense of community towards leadership effectiveness recorded was 0.727 and a significant value of 0.000 that shows the relationship. Third, the correlation value for alignment of values shows 0.528 with the significance 0.011 that which is statically significant correlation relationship between these two variables is. Lastly, the workplace spirituality towards leadership effectiveness correlation is 0.688 with the significant values is 0.004 . Overall, it shows that sense of community is the highest correlation coefficient compare to other variables. This indicates the sense of community that may lead for leadership effectiveness. The positive relationship of these two variables, has given positive relation to the leadership effectiveness.

\subsection{Hypothesis Test}

In Table 4.9 above, shows result of the hypothesis analysis. For meaningful work, the result indicates the significant level is 0.003 which is less than $\mathrm{p}>0.05$. Therefore, the research has rejected the hypothesis $\mathrm{H}_{0}$ and accepted the hypothesis $\mathrm{H}_{1}$. Second, for the sense of community there is a relationship to leadership effectiveness. The significant level 0.000 is that less than 0.05 so the $\mathrm{H}_{1}$ is accepted but the $\mathrm{H}_{0}$ has rejected. For the third relationship, there have statistically significant correlation between two variables because the significant level it's less than 0.05 . The hypothesis $\mathrm{H}_{1}$ is accepted and $\mathrm{H}_{0}$ is rejected. The overall hypothesis is been accepted because their significant level it's less than 0.05 . This result shows the workplace spirituality has given effect toward the leadership effectiveness. With the significant level is 0.004 the $\mathrm{H}_{0}$ rejected, $\mathrm{H}_{1}$ accepted. So, the third objective is being achieved and has statically significant correlation between workplace spirituality and leadership effectiveness. So, the workplace spirituality has given effect to the leadership effectiveness.

Table 4.9 - Result of hypothesis analysis

$\begin{array}{llll} & & & \end{array}$

\subsection{Discussion on Findings}

Earlier studies revealed deeper knowledge on workplace spirituality that leads to transfer of training. Further, it shows that adoption from a model of transfer process by Baldwin \& Ford (1988) to encourage employees to apply the importance of workplace spirituality so that they understand the concept of working properly in order to improve the training effectiveness in an organization. This study provides an insight into the concept of workplace spirituality by examining its effect on the transfer of training. Three dimensions of workplace spirituality which are meaning at work, community at work and positive organizational purpose have been take into account for discovering workplace spirituality relationship with transfer of training. Furthermore, this study will help to increase the awareness of employees in $\mathrm{X}$ company about workplace spirituality will be increased. This is important to ensure the positive transfer of knowledge of employees from training place to the workplace. In addition, this study will help the employees to understand themselves and what their needs to contribute to the organization.

Based on the conceptual framework, there are four variables that are used as an independent variable for this research which are workplace spirituality as the main point, meaningful work, sense of community and alignment of value (Petchsawang \& Duchon, 2009). As a conceptual framework demonstrated a relationship between workplace spirituality and leadership effectiveness. There is some limitation to this study. First, the method that been used to collect data is questionnaire is easy and quick, but there have some respondents that cannot answer the questionnaire due to work constraints and a big responsibility. Besides that, using the questionnaire may lead to the respondent not answered the entire question and make data invalid. Lastly, using volunteer as a sample make a difficult to reach the entire volunteer because the schedule is not fixed. And make more time to collect the questionnaires has been constructed. The workplace spirituality an independent variable and leadership effectiveness as a dependent variable. From the result that has been 
obtained in result analysis, the four hypotheses have shown a positive correlation. And all the independent variable is workplace spirituality has a significant relationship with the dependent variable is leadership effectiveness. According to Deshpande (2012), workplace spirituality can give impact to all employees and also leaders as well the organization outcome. From the analyses that show the workplace spirituality can give effect to leadership effectiveness.

\section{Recommendation}

Based on the finding of the study, several recommendations can be made. Firstly, workplaces spirituality among the volunteer. The volunteer should particularly concern on the workplace spirituality in making the condition in the workplaces it is better. Also, the volunteer needs to care about each other to make the productivity workplaces and can make the spirituality in workplaces it is better. So, it may be effective on the performance of the organization. Secondly, the volunteer needs to connect themselves with the mission and the goals of the organization so they can energize themselves and can feel the positive effect about the values in the organization. Thirdly, from the result, there no relationship between workplace spirituality and leadership effectiveness, so for the future research could do research using another component as an independent variable that can influence leadership effectiveness. Lastly, the leader needs to more effectively make the schedules for their employees to make the work more effective and the objective each of the work can be achieved together.

\section{Conclusion}

Workplaces spirituality is important for the organization. The workplaces spirituality in workplaces can influence the productivity of the organization. This higher workplace spirituality can affect the environment in the workplace. In order to ensure the workplaces spirituality always influences the environment of the workplaces, they should see attribution of workplaces spirituality before making the decision. In this research result, there three component which is meaningful work, sense of community and alignment of value that has positive correlation affect the leadership effectiveness. And the main point or independent variable is also shown a positive correlation. Overall, the data analysis has revealed there no relationship for all hypotheses towards leadership effectiveness.

\section{Acknowledgement}

The authors wish to thank those who graciously gave their time, kind co-operation and encouragement which help us in completion of this study.

\section{References}

Ashmos, D. P., \& Duchon, D. (2000). Spirituality at work: A conceptualization and measure. Journal of management inquiry, 9(2), 134-145.

Bhatia, S., \& Arora, E. (2017). Workplace spirituality: an employer-employee perspective. International Journal of Innovative Research and Development, 6(1), 106-111.

Benefiel, M., Fry, L. W., \& Geigle, D. (2014). Spirituality and religion in the workplace: History, theory, and research. Psychology of Religion and Spirituality, 6(3), 175.

Daniel, J. L., \& Chatelain-Jardon, R. (2015). The relationship between individual spirituality, organizational commitment and individual innovative behavior. Management Research and Practice, 7(1), 5.

Deshpande, A. (2012). Workplace spirituality, organizational learning capabilities and mass customization: An integrated framework. International Journal of Business and Management, 7(5), 3.

Duckett, H., \& Macfarlane, E. (2003). Emotional intelligence and transformational leadership in retailing. Leadership \& Organization Development Journal, 24(6), 309-317.

Ford, J. (2010). Studying leadership critically: A psychosocial lens on leadership identities. Leadership, 6(1), 47-65.

Houston, G. G. (2014). Spirituality and leadership: Integrating spirituality as a developmental approach of improving overall leader effectiveness.

Jenkins, R. (2013). Pierre bourdieu. Routledge.

Kelly, J. F., Stout, R. L., Magill, M., Tonigan, J. S., \& Pagano, M. E. (2011). Spirituality in recovery: A lagged mediational analysis of Alcoholics Anonymous' principal theoretical mechanism of behavior change. Alcoholism: Clinical and Experimental Research, 35(3), 454-463.

Krejcie, R. V., \& Morgan, D. W. (1970). Determining sample size for research activities. Educational and psychological measurement, 30(3), 607-610. 
Kumari, N. (2014). Spirituality at work place: a macroscopic shift from business to ethics. Abhinav national monthly refereed journal of research in commerce \& management.

Marschke, E., Preziosi, R., \& Harrington, W. J. (2011). How sales personnel view the relationship between job satisfaction and spirituality in the workplace. Journal of Organizational Culture, Communications and Conflict, 15(2), 71.

Munda, S. S. (2011). Workplace Spirituality: Rekindling the Humanitarian Climate to Improve Organizational Outcomes. In Twelfth AIMS International Conference on Management (pp. 2509-2515).

Nisbett, R. (2004). The geography of thought: How Asians and Westerners think differently... and why. Simon and Schuster.

Ololube, N. P. (2013). Educational management, planning and supervision: model for effective implementation. Owerri, Nigeria: SpringField Publishers.

Petchsawang, P., \& Duchon, D. (2009). Measuring workplace spirituality in an Asian context. Human Resource Development International, 12(4), 459-468.

Saks, A. M. (2011). Workplace spirituality and employee engagement. Journal of management, spirituality \& religion, 8(4), 317-340.

Sethuraman, K., \& Suresh, J. (2014). Effective leadership styles. International Business Research, 7(9), 165.

Sukanya, M. (2014). Leadership Effectiveness and Workplace Spirituality: Employees Perspective. International Journal of Management.

Weitz, E., Vardi, Y., \& Setter, O. (2012). Spirituality and organizational misbehavior. Journal of Management, Spirituality \& Religion, 9(3), 255-281.

Wulandari, F. (2014). Spirituality in workplace, individual spirituality and work behaviour: the studi of higher education in Indonesia. Individual Spirituality and Work Behaviour: The Studi of Higher Education in Indonesia (February 17, 2014).

Zandi, G., Sulaiman, M., \& Rashed, N. (2015). Spirituality and leader's effectiveness: an Islamic perspective. Asian Economic and Financial Review, 5(1), 155-166. 